\title{
ANALISIS STRATEGI PENINGKATAN LOYALITAS CUSTOMER B2B E-COMMERCE, STUDI KASUS: GMF AEROTRADE DI PT. GMF AEROASIA
}

\author{
Erlinda Muslim, Ghassani Shabrina, Indira Prianda \\ Program Studi Teknik Industri, Fakultas Teknik, Universitas Indonesia \\ Kampus Baru UI Depok 16424 \\ e-mail:erlinda@eng.ui.ac.id
}

\begin{abstract}
Abstrak
A eroAsia GMF PT menawarkan salah satu Business-to-Business ECommerceterbesar di Indonesia yang bergerak di bidang MRO (Maintenance, Repair, and Overhaul) memiliki bisnis maintenance pesawat dan sebagai distributor material komponen pesawat yang bernama GMF AeroTrade. GMF AeroTrade merupakan bentuk platform E-Commerce berbentuk web storeyang baru berdiri sejak awal tahun 2017. Meningkatnya kebutuhan material setiap tahunnya memberikan dampak yang cukup besar terhadap kompetitifnya pasar distributor kebutuhan komponen pesawat terbang. Dengan perubahan baru dengan diadakannya platform berbasis E-Commerce ini di GMF AeroTrade dan juga melihat adanya banyak kompetitor lainnya di dunia, peran loyalitas pelanggan sangat berpengaruh terhadap keuntungan perusahaan. Maka dari itu GMF AeroTrade membutuhkan strategi yang kuat untuk dapat meningkatkan loyalitas pelanggan (Customer Loyalty). Dalam pembuatan strategi tersebut akan diteliti dari pengaruh faktor Image, Perceived Quality, Perceived Value, dan Customer Satisfaction terhadap loyalitas pelanggan (Customer Loyalty) dengan menggunakan metode SEM-PLS. Selain itu, digunakan metode Importance-Performance Analysis untuk mendapatkan action items beserta tingkat prioritas pelaksanaan untuk setiap action items. Penelitian ini mengambil pelanggan yang aktif melakukan transaksi pembelian di GMF AeroTrade. Hasil dari penelitian ini merupakan strategi untuk meningkatkan loyalitas pelanggan (Customer Loyalty) GMF AeroTrade, sehingga dapat bersaing dengan kompetitor distributor material komponen pesawat lainnya yang ada di dunia.
\end{abstract}

Kata Kunci:Customer Loyalty, Image, Perceived Quality, Perceived Value, Customer Satisfaction

\section{PENDAHULUAN}

Salah satu bisnis yang sedang marak di kalangan perusahaan dan melaju di tingkat yang lebih inovatif adalah bisnis E-commerce B2B. Jenis E-commerce Business to Business atau
B2B adalah bisnis yang dilakukan oleh orang atau pihak yang saling memiliki kepentingan bisnis, atau bisa juga disebut bisnis antar perusahaan. Dalam perkembangan E-Commerce secara global ini, angka bisnis B2B lebih pesat 
dibandingkan bisnis B2C. Walaupun dalam perkembangan E-commerce secara global saat ini pasar B2C telah mendapatkan atensi pasar yang besar, namun ternyata angka bisnis B2B lebih pesat dibandingkan bisnis B2C. Saat ini, angka penjualan B2B E-commerce mencapai \$ 5,5 miliar (tahun 2017). Gambar 1.1 menyatakan bahwa telah diproyeksikan juga oleh (Frost dan Sullivan, 2017) bahwa B2B $E$ commerce akan mencapai penjualan $2 \mathrm{x}$ lebih besar dari B2C E-commerce di tahun 2020, yaitu sebesar $\$ 6,7$ miliar (Statista, 2015). Hal ini dikarenakan $57 \%$ dproses buying decisions di Ecommerce B2B dilakukan sebelum terlibat dengan suatu penjualan. Maka dari itu situs E-commerce B2B menjadi alat penjualan yang dapat membantu dan memudahkan proses pembelian.

Salah satu bisnis yang sudah cukup dikenal di bisnis B2B di pasaran aircraft pesawat adalah Bisnis MRO maskapai penerbangan. Bisnis penerbangan merupakan salah satu industri yang paling kompetitif di lingkungan ekonomi, setidaknya dari sudut pandang regional (Jarach, 2002). Kini dengan semakin cepatnya penggunaan Internet secara global, industri penerbangan terpaksa pindah ke tahap yang lebih inovatif dengan menggunakan sistem E-commerce untuk proses bisnisnya.Berdasarkan Airbus Global Market Forecast 2017 2036, dikatakan bahwa diperkirakan akan tumbuh armada penerbangan komersial in-service dari hampir 25.000 pesawat pada awal 2014 menjadi lebih dari 37.000 pada tahun 2024. Dalam kurun waktu itu dunia memerlukan 35.000 pesawat terbang jenis baru. Hal ini didasari dengan meningkatnya pertumbuhan industri dan penerbangan dunia yang tumbuh sebesar $4,4 \%$ per tahunnya, sementara pertumbuhan ekonomi dunia hanya mencapai angka 1,5 hingga 2 persen per tahunnya.

Salah satu perusahaan MRO terbesar di Indonesia saat ini adalah PT. GMF AeroAsia. GMF AeroAsia bergerak di bisnis B2B MRO untuk aircrafts (armada penerbangan) dan juga sebagai distributor aircraft parts (komponenpesawat). Yang dimana saat ini sudah mulai mengembangkan ranah bisnisnya di bidang E-commerce dengan diadakannya platform berbasis webstore yang bernama GMF AeroTrade. GMF AeroTrade yang telah menjadi fokusan bisnis penjualan material selain servis aircraft maintenance di GMF AeroAsia ini sudah berjalan sejak awal tahun 2017 dibawah unit TMM Material Trading.Secara garis besar, produk yang 
dijual di GMF AeroTrade dapat dikategorikan menjadibarangConsumable (material habis sekali pakai), Airframe, Services, dan Engine(mesin pesawat). Sampai saat ini, terdapat sekitar 180.000 jenis material pesawat terbang yang disediakan oleh GMF AeroAsia.

Untuk meningkatkan pelayanan pelanggan GMF AeroTrade, diperlukan suatu metode pengukuran untuk mengetahui tingkat kepuasan dan loyalitas customer dengan mengetahui faktor-faktor yang mempengaruhinya. Loyalitas pelanggan secara umum dapat diartikan sebagai kesetiaan seseorang atas suatu produk, baik barang maupun jasa tertentu sehingga menimbulkan perilaku untuk membeli secara rutin atau berulang kali (Liu et al., 2011). Faktor - faktor image, perceived

\section{.METODE}

\subsection{Model dan Hipotesis Penelitian}

Model penelitian digambarkan pada Gambar 1 .

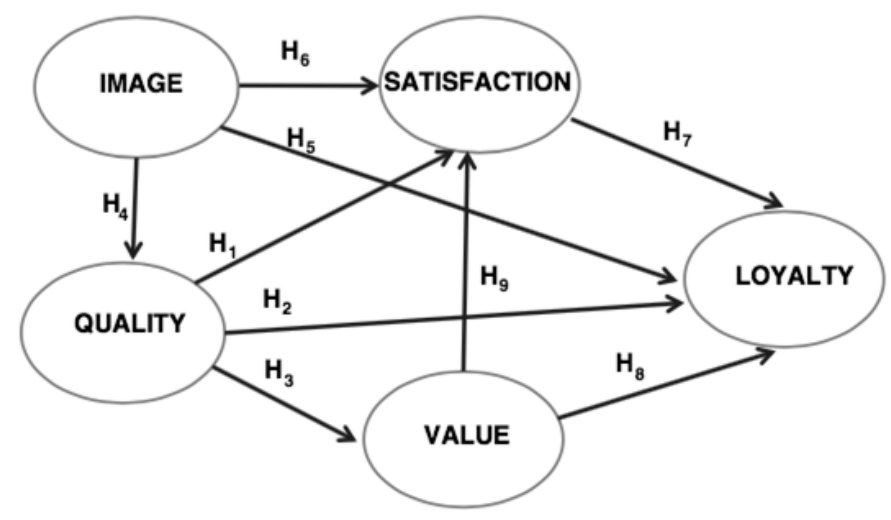

Gambar 1. Model Penelitian Hubungan Antara Faktor image, perceived quality, perceived value, dan customer satisfaction terhadap customer loyalty

(Sumber : Akinci \& Ding, 2011) quality, perceived value, customer satisfaction dan customer loyaltyakan menentukan bagaimana hubungan antara suatu E-commerce dengan penggunanya dapat ditingkatkan (Turban et al). Dengan demikian diharapkan dapat mencapai loyalitas pelanggannya. Maka dari itu, untuk menghadapi persaingan yang ketat dengan kompetitor di bidang aircraft spareparts yang berbentuk E-commerce, GMF AeroTrade harus mempunyai strategi yang kuat dan tepat untuk meningkatkan kepuasan dan loyalitas pelanggannya. Dengan mengetahui hubungan keempat faktor tersebut maka dapat dianalisis faktor apa saja yang paling berpengaruh untuk mempertahankan dan meningkatkan kepuasan serta loyalitas pelanggan GMF AeroTrade 
Hipotesis Penelitian

H1 :Perceived Quality secara langsung memiliki efek positif terhadap Customer Satisfaction

$\mathrm{H} 2$ :Perceived Quality secara langsung memiliki efek positif terhadap Customer Loyalty

H3 :Perceived Quality secara langsung memiliki efek positif terhadap

Perceived Value

$\mathrm{H} 4$ :Image secara langsung memiliki efek positif terhadap Perceived Quality

H5 :Image secara langsung memiliki efek positif terhadap Customer Loyalty

H6 :Image secara langsung memiliki efek positif terhadap Customer

Satisfaction

H7 :Customer Satisfaction secara langsung memiliki efek positif terhadap Customer Loyalty

H8 :Perceived Value secara langsung memiliki efek positif terhadap Customer Loyalty

H9 :Perceived Value secara langsung memiliki efek positif terhadap Customer Satisfaction

\subsection{Perancangan dan Penyebaran Kuesioner}

\subsubsection{Perancangan Kuesioner Berdasarkan Referensi \\ Kuesioner yang disusun dalam} penelitian ini sudah berdasarkan acuan referensi mengenai loyalitas pelanggan di B2B e-marketplace (Janita \& Miranda, 2013) dan menggunakan kuesioner berbentuk scaled response question. Scaled response question merupakan pertanyaan yang dinilai dari tingkat kesesuaian responden terhadap pernyataan dalam kuesioner dari sudut pandang responden. Jenis pertanyaan ini menggunakan skala untuk mengukur tingkat setuju atau tidak setujunya responden terhadap setiap pernyataan dalam kuesioner.

Pada penelitian ini, pernyataan scaled-response question dirumuskan dan dibuat berdasarkan penelitian dari berbagai literatur terkait pengukuran dimensi loyalitas pelanggan (customer loyalty). Dirumuskan dengan pernyataan scaled-response question serta digunakan skala likert tujuh tingkat dengan pertimbangan kemudahan pengolahan data secara statistik, serta lebih cepat dibuat dan dipahami oleh responden (Yoo et al., 2000).

1.2.2. Perancangan Kuesioner Berdasarkan Expert Opinion

Melalui hubungan antara variabel laten dan indikator yang telah dinilai oleh para ahli dan diseleksi dengan metode Geomean, maka dibentuk model awal penelitian yang menggabungkan variabel laten dan indikatornya. 
Variabel Perceived Quality memiliki 12 indikator, Image memiliki 2 indikator, Customer Loyalty memiliki 2 indikator, Customer Satisfaction memiliki 2 indikator, dan Perceived Value memiliki 2 indikator. Total indikator yang diguanakan dalam penelitian ini adalah 20 indikator variabel terukur dan terdapat 5 variabel laten.

\subsection{Penyebaran Kuesioner}

Penyebaran kuesioner akan dilakukan menggunakan layanan survey di internet milik GMF AeroAsia yaitu surveymonkey.com dengan jangka waktu penyebaran selama 2 bulan, mulai dari tanggal 15 Januari 2018 - 15 Maret 2018. Responden yang dapat dikatakan valid untuk penelitian ini adalah customer yang pernah melakukan transaksi pembelian material pesawat (aircraft parts) di website GMF AeroTrade dalam periode bulan Januari 2017 hingga bulan Maret 2018. Pada penelitian ini, total responden yang mengisi kuesioner sebanyak 33 responden.

1.4. Pengolahan Data

Pengolahan data dilakukan dengan dengan pendekatan PLS - SEM (Partial Least Square) dengan menggunakan perangkat lunak SmartPLS. Kuesioner yang digunakan melalui uji reliabilitas dan vailiditas dengan Cronbach Alpha dan Uji Barlett yang sudah terbukti reliabel dan valid.

\subsubsection{Spesifikasi Model}

Spesifikasi model dibuat untuk mempresentaskan permasalahan yang ingin diteliti dalam penelitian. Hubungan antara variabel laten: PQ dipengaruhi oleh SAT, LOY, dan VA; IMA dipengaruhi oleh PQ, LOY, dan SAT; SAT dipengaruhi oleh LOY; VA dipengaruhi oeh LOY dan SAT.Dari spesifikasi yang telah dijabarkan di atas, dapat dibentuk sebuah path diagram. Gambar 2 menggambarkan path diagram yang akan diestimasi dan dianalis dalam penelitian ini. 


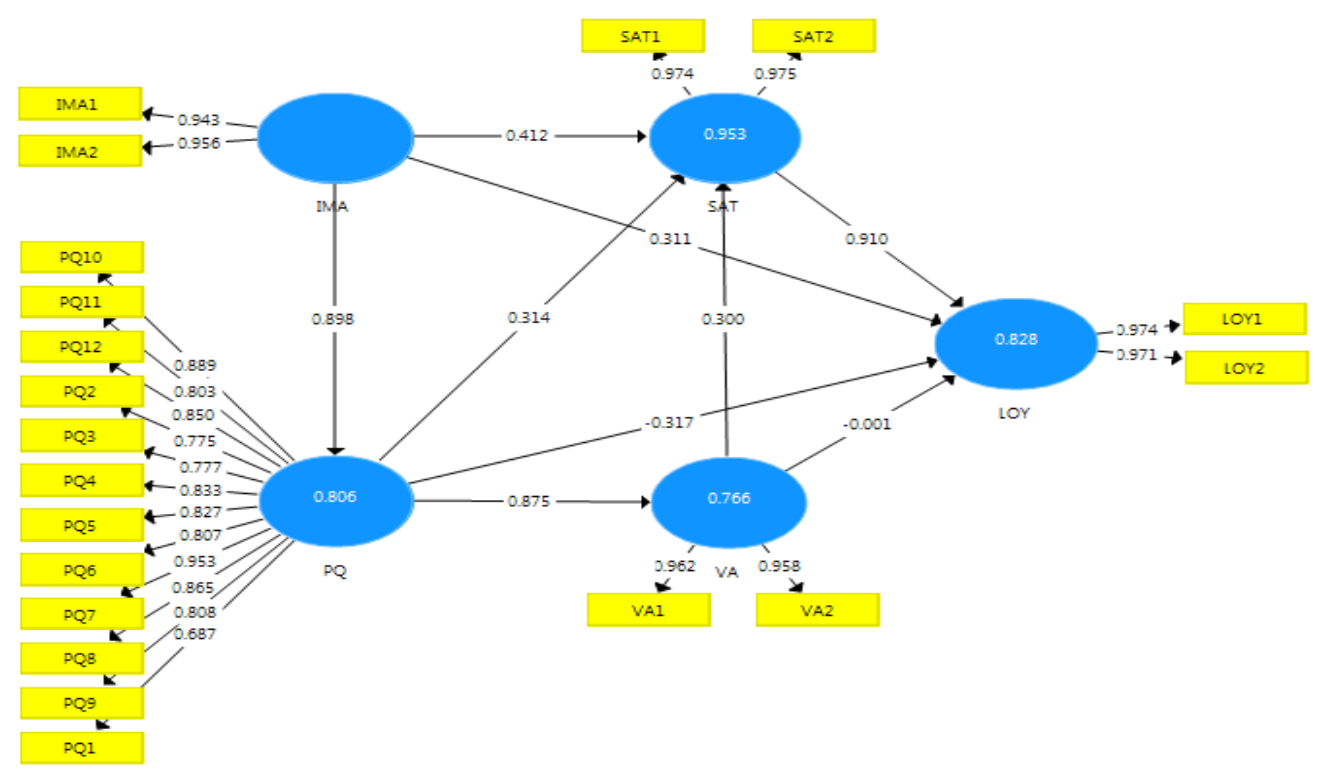

Gambar 2. Path Diagram Model Penelitian

\subsubsection{Penilaian Model Pengukuran}

Tahapan penilaian model pengukuran dilakukan untuk mengetahui seberapa baik indicator yang digunakan didalam model dapat mengukur variabel latennya. Terdapat tiga indikator yang dapat menilai suatu model pengukuran, yaitu internal consistency reliability, convergent validity dan discriminant validity.

\subsubsection{Respesifikasi Model dan Penilaian Model Pengukuran Hasil Respesifikasi}

Penghapusan indikator PQ1 menyebabkan terjadinya respesifikasi model dan akan mempengaruhi hasil estimasi model.Setelah model direspesifikasi, maka model kembali diestimasi dengan menggunakan fungsi kalkulasi PLS Algorithm. Setelah proses estimasi selesai dilakukan, maka hal yang dilakukan adalah melakukan penilaian ulang terhadap model pengukuran yaitu dari internal consistency reliability, convergent validity dan discriminant validity. Penilaian internal consistency reliability dengan cara melihat nilai composite reliability dan Cronbach's Alpha setiap variabel.

\subsubsection{Penilaian Model Struktural}

Ada empat langkah yang harus dilakukan untuk menilai model struktural, yaitu menilai kolinearitas model, menilai signifikansi dan relevansi model, menilai tingkat $\mathrm{R}^{2}$ dan menilai ukuran effect size $\mathrm{f}^{2}$.

Langkah pertama yaitu menilai kolinearitas model yang dilihat berdasarkan nilai variance inflation factor (VIF). Dalam penilaian ini, model sudah harus dipastikan tidak memiliki kolinearitas ganda. Tidak adanya multikolinearitas diindikasikan apabilia nilai VIF 
berada di bawah 5 (Heir et al, 2011). Nilai VIF hanya terdapat pada IMA $\rightarrow$ PQ, IMA $\rightarrow$ SAT, $\mathrm{PQ} \rightarrow \mathrm{VA}$, dan VA $\rightarrow$ SAT. Keempat gabungan variabel ini memperlihatkan bahwa hanya variabel diatas yang hanya memiliki kolinearitas yang baik.

Langkah kedua yang dilakukan adalah melihat signifikansi dan relevansi antar hubungan variabel. Untuk melihat signifikansi model dinilai dari koefisien lintasan (path coefficient) yang mewakili hubungan antar variabel laten dan juga gabungan dari kedua hubungan variabel laten yang disebut dengan Total Effects. Dalam pengukuran kali ini harus dilakukan dengan metode bootstrapping terhadap sampel. Pengujian dengan bootstrap dimaksudkan untukmeminimalkan masalah ketidaknormalan data penelitian. Selanjutnya, dilakukan penilaian koefisien determinansi $\left(\mathrm{R}^{2}\right)$. Koefisien determinansi menunjukkan ukuran akuransi prediktif model dan dihitung berdasarkan korelasi kuadrat antara nilai asli dan nilai prediktif konstruk endogen tertentu. Selain nilai $\mathrm{R}^{2}$, nilai lain yang perlu dilihat adalah nilai effect size $\left(\mathrm{f}^{2}\right)$ dari masing-masing konstruk. Nilai effect size $\left(\mathrm{f}^{2}\right)$ menunjukkan ukuran dampak dari penghilangan konstruk tertentu terhadap konstruk endogen

\subsection{Perumusan Action Items atau Atribut}

Perumusan action items atau atribut strategi ini dirumuskan melalui hasil diskusi dengan beberapa ahli dari unit material trading GMF AeroTrade. Berdasarkan hasil diskusi tersebut, didapatkan 13 total action items berdasarkan keempat faktor dalam penelitian yang digunakan GMF AeroTrade sebagai strategi peningkatan loyalitas pelanggannya

1.6. Pengolahan Action Items dengan Customer Satisfaction Index (CSI)

Tabel 1. Pengolahan Data Customer Satisfaction Index (CSI)

\begin{tabular}{|c|c|c|c|c|}
\hline \multirow{4}{*}{ Variabel } & $\begin{array}{c}\text { Action } \\
\text { Item }\end{array}$ & $\begin{array}{c}\text { Importance } \\
\text { (I) }\end{array}$ & $\begin{array}{c}\text { Satisfaction } \\
\text { (S) }\end{array}$ & Skor (I x S) \\
\hline \multirow{4}{*}{$\begin{array}{c}\text { Perceived } \\
\text { Quality }\end{array}$} & $\mathbf{1}$ & 4.48 & 3.52 & 15.77 \\
\cline { 2 - 5 } & $\mathbf{2}$ & 4.52 & 3.10 & 14.00 \\
\cline { 2 - 5 } & $\mathbf{3}$ & 4.52 & 3.52 & 15.94 \\
\cline { 2 - 5 } & $\mathbf{4}$ & 3.29 & 3.38 & 11.11 \\
\hline \multirow{3}{*}{ Image } & $\mathbf{6}$ & 4.05 & 3.71 & 15.03 \\
\cline { 2 - 5 } & $\mathbf{7}$ & 4.76 & 3.10 & 8.55 \\
\hline \multirow{2}{*}{$\begin{array}{c}\text { Perceived } \\
\text { Value }\end{array}$} & $\mathbf{8}$ & 3.95 & 3.90 & 17.29 \\
\cline { 2 - 5 } & $\mathbf{9}$ & 4.24 & 3.14 & 16.37 \\
\hline $\begin{array}{c}\text { Customer } \\
\text { Satisfaction }\end{array}$ & $\mathbf{1 0}$ & 4.48 & 3.10 & 13.34 \\
\cline { 2 - 5 } & $\mathbf{1 1}$ & 4.67 & 3.52 & 16.44 \\
\hline \hline & TOTAL & $\mathbf{4 5 , 3 8}$ & & $\mathbf{1 5 9 , 7 1}$ \\
\hline
\end{tabular}




$$
\text { CSI }=\frac{159,71}{5 \times 45,38} \times 100 \%=70,39 \%
$$

Nilai Customer Satisfaction Index (CSI) yang diperoleh adalah sebesar 70,39\%.. Analisis menggunakan penilaian CSI ini telah mengaitkan antara tingkat kepentingan (importance) suatu action item atau atribut yang dimiliki objek terentu dengan kepuasan (satisfaction) yang dirasakan oleh customer.

1.7. Pengolahan Action Items dengan Importance - Performance Analysis (IPA)

Tabel 2. Pengolahan Data Importance - Performance Analysis (IPA)

\begin{tabular}{|c|c|c|c|c|c|}
\hline Variabel & Action Item & Mean (y) & Sumbu-y & Mean (x) & Sumbu-x \\
\hline \multirow{5}{*}{$\begin{array}{c}\text { Perceived } \\
\text { Quality }\end{array}$} & 1 & 4,48 & \multirow{5}{*}{4,171} & 3,52 & \multirow{5}{*}{3,448} \\
\hline & 2 & 4,52 & & 3,10 & \\
\hline & 3 & 4,52 & & 3,52 & \\
\hline & 4 & 3,29 & & 3,38 & \\
\hline & 5 & 4,05 & & 3,71 & \\
\hline \multirow{2}{*}{ Image } & 6 & 2,76 & \multirow{2}{*}{3,595} & 3,10 & \multirow{2}{*}{3,5} \\
\hline & 7 & 4,43 & & 3,90 & \\
\hline \multirow{2}{*}{ Perceived Value } & 8 & 3,95 & \multirow{2}{*}{4,095} & 4,14 & \multirow{2}{*}{3,881} \\
\hline & 9 & 4,24 & & 3,62 & \\
\hline \multirow{2}{*}{$\begin{array}{c}\text { Customer } \\
\text { Satisfaction }\end{array}$} & 10 & 4,48 & \multirow{2}{*}{4,571} & 3,10 & \multirow{2}{*}{3,31} \\
\hline & 11 & 4,67 & & 3,52 & \\
\hline
\end{tabular}

Responden yang memberikan nilai IPA untuk setiap action items atau atribut berjumlah 21 orang.

\subsection{Pemetaan Keempat Faktor Customer Loyalty Pada Kuadran IPA}

Setelah pemetaan action items untuk masing-masing faktor, dilakukan pemetaan antar keempat faktor tersebut untuk melihat tingkat importance dan satisfaction tiap faktor pada penelitian ini terhadap peningkatan Customer Loyalty. Pemetaan keempat faktor ke dalam kuadran IPA dilakukan dengan menghitung nilai rata-rata dari mean masing-masing action items untuk setiap faktor. 


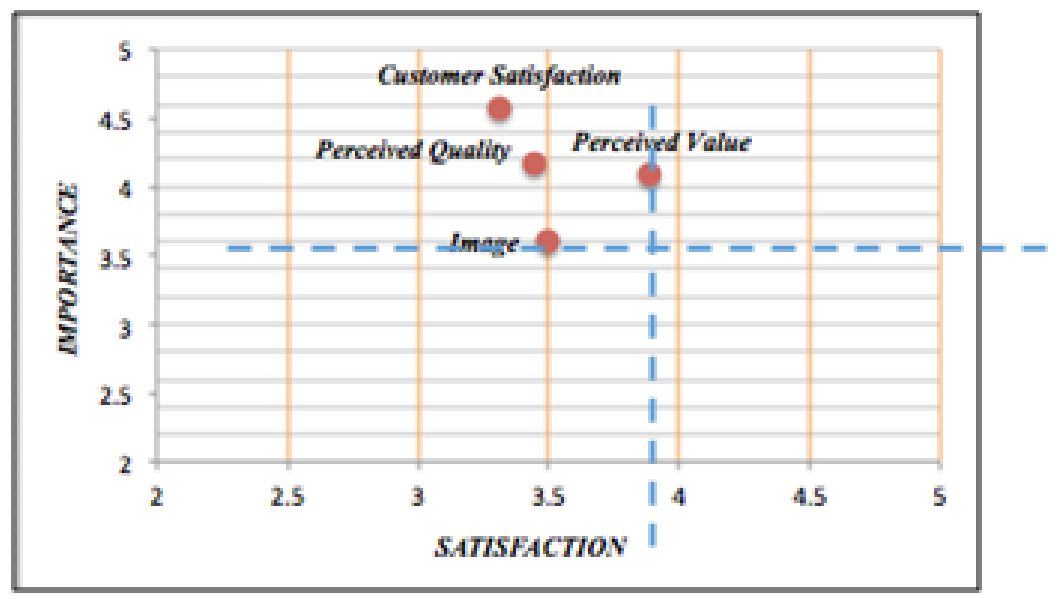

Gambar 3. Kuadran IPA Antar Keempat Faktor Customer Loyalty

Pada Kuadran I terdapat action items dari faktor Perceived Quality dan Customer Satisfaction. Pada Kuadran III terdapat action item dari faktor Image. Dan pada Kuadran IV terdapat action item dari faktor Perceived Value.

\section{HASIL DAN PEMBAHASAN}

\subsection{Analisis Hubungan Kausal}

\subsubsection{Analisis $t$-value}

Pengukuran $t$-value bertujuan untuk menunjukkan pengaruh antara satu variabel laten dengan variabel laten lainnya. Suatu variabel laten dikatakan memiliki pengaruh terhadap variabel laten lainnya jika memiliki $t$-value $\geq 1.96$ pada persamaan struktural (Wijanto, 2008). Jika t-value memenuhi persyaratan, maka hal ini mengindikasikan bahwa koefisien persamaan struktural dapat dianggap signifikan dan hipotesis dapat diterima. Maka selain hipotesis 2 dan 8, seluruh hipotesis 1 hingga 9 diterima.

\subsubsection{Analisis Koefisien Determinansi (R2)}

Koefisien determinansi atau $\mathrm{R}^{2}$ pada persamaan regresi berfungsi untuk menunjukkan seberapa besar pengaruh suatu variabel dalam menjelaskan variabel lainnya. Nilai $\mathrm{R}^{2}$ menunjukkan seberapa besar variabel eksogen mewakili variabel endogen (Wijanto, 2008). . Sesuai dengan data pada Tabel 3.13 dengan pengolahan data menggunakan SmartPLS, terlihat bahwa nilai $\mathrm{R}^{2}$ sebesar 0,824 yang menandakan bahwa customer satisfaction, perceived quality, perceived value, dan image menjelaskan $82,4 \%$ varian customer loyalty. 


\subsection{Analisis Customer Satisfaction Index (CSI)}

Hasil dari Customer Satisfaction Index (CSI) memiliki nilai sebesar 70,39 \%. Hal ini menggambarkan bahwa customer GMF AeroTrade sudah cukup puas atas kinerja layanan yang diberikan oleh pihak GMF AeroTrade, tetapi dirasakan masih belum maksimal secara keseluruhan. Maka dari itu diperlukan suatu pengukuran strategi yang tepat untuk meningkatkan kinerja layanan GMF AeroTrade dan dapat berdampak langsung terhadap kepuasan dan loyalitas customer.

\subsection{Analisis Importance - Performance Analysis (IPA)}

\subsubsection{Analisis Kuadran Action Items}

Analisis terhadap pemetaan setiap action items pada empat-kuadran IPA dilakukan untuk mengetahui langkah yang sebaiknya dilakukan oleh GMF AeroTrade untuk action items yang dilakukan, sehingga strategi peningkatan loyalitas pelanggan dapat lebih efektif dan efisien.

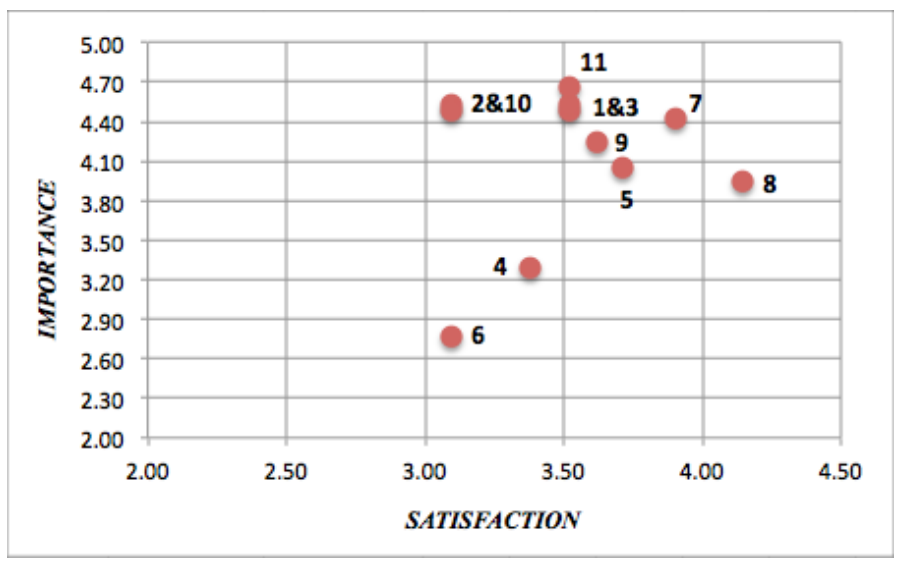

Gambar 4. Kuadran IPA dari Seluruh Action Items

Berdasarkan Gambar 4, dapat dilihat bahwa ke-11 action items tersebar pada keempat kuadran tersebut, yaitu :

a. Kuadran I - Concentrate Here (Importance Tinggi \& Satisfaction Rendah)

Tabel 3. Penjelasan Action Items Kuadran I

Berdasarkan Tabel 3, terlihat pada Kuadran I dapat disimpulkan bahwa kedua atribut diatas yaitu action item 2 dan 10 memiliki tingkat kepuasan (satisfaction) yang rendah dalam meningkatkan loyalitas pelanggan (customer loyalty). Namun tingkat kepentingan (importance) yang dirasakan pelanggan dapat dikatakan cukup tinggi, sehingga strategi tersebut harus bisa ditingkatkan lebih baik lagi untuk dapat mencapai kepuasan pelanggan yang tinggi.

b. Kuadran II - Keep Up The Good Work (Importance Tinggi \&Satisfaction Tinggi) 
Tabel 4.Penjelasan Action Items Kuadran II

\begin{tabular}{|c|c|l|}
\hline Item & Variabel & \multicolumn{1}{c|}{ Atribut atau Action Items } \\
\hline 2 & Perceived Quality & $\begin{array}{l}\text { It takes a short time to complete the whole transaction in GMF } \\
\text { AeroTrade }\end{array}$ \\
\hline 10 & Customer Satisfaction & $\begin{array}{l}\text { GMF AeroTrade salesperson provides a friendly service and have } \\
\text { knowledge about the products }\end{array}$ \\
\hline
\end{tabular}

Berdasarkan Tabel 4 dapat disimpulkan bahwa keenam atribut diatas yaitu action items 1 , 3, 7, 9, dan 11 memiliki tingkat kepentingan (importance) dan kepuasan (satisfaction) yang

\begin{tabular}{|c|c|l|}
\hline Item & Variabel & \multicolumn{1}{c|}{ Atribut atau Action Items } \\
\hline \multirow{2}{*}{$\mathbf{1}$} & Perceived Quality & $\begin{array}{l}\text { Customer received softcopy of the part ceritificate's (before the } \\
\text { product is delivered) }\end{array}$ \\
\cline { 3 - 3 } & Image & $\begin{array}{l}\text { Feep innovate the services in GMF AeroTrade to build good image } \\
\text { and to maintain good relation with customers }\end{array}$ \\
\hline $\mathbf{7}$ & Perceived Value & $\begin{array}{l}\text { Get an adequate profit margin from the products and services that } \\
\text { GMF AeroTrade offers to the customers }\end{array}$ \\
\hline $\mathbf{9}$ & Customer Satisfaction & GMF AeroTrade responds to the customer requests quickly \\
\hline
\end{tabular}

relatif tinggi. Hasil dari pemetaan pada Kuadran ini telah sesuai dengan tingkat yang diinginkan oleh pihak GMF AeroTrade. Dengan adanya hasil ini, maka GMF AeroTrade bisa lebih mempertahankan kepuasan yang sudah relatif baik untuk kepentingan akan loyalitas pelanggannya.

c. Kuadran III - Low Priority (Importance Rendah \&Satisfaction Rendah)

Tabel 5. Penjelasan Action Items Kuadran III

\begin{tabular}{|c|l|l|}
\hline Item & Variabel & \multicolumn{1}{c|}{ Atribut atau Action Items } \\
\hline $\mathbf{5}$ & Perceived Quality & $\begin{array}{l}\text { The website provides details information about the products and } \\
\text { services that GMF AeroTrade offers }\end{array}$ \\
\hline $\mathbf{8}$ & Perceived Value & $\begin{array}{l}\text { The aircraft products price offered by GMF AeroTrade is competitive } \\
\text { with the market price standards }\end{array}$ \\
\hline
\end{tabular}

Berdasarkan Tabel 5, dapat disimpulkan bahwa kedua atribut diatas yaitu action items 4 dan 6 tidak memiliki tingkat kepentingan (importance) dan kepuasan (satisfaction) yang tinggi dalam meningkatkan loyalitas pelanggan (customer loyalty). Sehingga, GMF AeroTrade dapat tidak terlalu memfokuskan action items tersebut dan lebih berfokus pada action items lain yang memiliki tingkat kepentingan dan kepuasan lebih tinggi 
d. Kuadran IV - Possible Overkill (Importance Rendah \&Satisfaction Tinggi)

Tabel 6. Penjelasan Action Items Kuadran IV

\begin{tabular}{|c|c|l|}
\hline Item & Variabel & \multicolumn{1}{|c|}{ Atribut atau Action Items } \\
\hline $\mathbf{4}$ & Perceived Quality & $\begin{array}{l}\text { Keep the customer updated with the new products that GMF } \\
\text { AeroTrade sells (by email or any promotion tools) }\end{array}$ \\
\hline $\mathbf{6}$ & Image & $\begin{array}{l}\text { Invite customers to GMF AeroAsia exhibition to introduce and } \\
\text { launch new products of GMF AeroTrade }\end{array}$ \\
\hline
\end{tabular}

Berdasarkan Tabel 6. dapat disimpulkan bahwa atribut diatas yaitu action items 5 dan 8 tidak memiliki tingkat kepentingan (importance) yang rendah dalam meningkatkan loyalitas pelanggan (customer loyalty). Namun, tingkat kepuasan (satisfaction) yang dirasakan oleh pelanggan cukup tinggi, sehingga penyesuaian kepuasan atas strategi tersebut dapat dilakukan agar lebih efektif dan efisien.

\subsection{Analisis Prioritas Action Items}

Analisis terhadap prioritas pada ke-11 action items pada masing-masing kuadran dilakukan dengan cara menghitung gap (kesenjangan) antara importance (kepentingan) customer dengan satisfaction (kepuasan) pada setiap action items. Nilai gap didapatkan dari hasil nilai rata-rata satisfaction (kepuasan) customer dikurangi nilai rata-rata importance (kepentingan) pada setiap action items.

Tabel 7. Nilai Gap untuk Setiap Action Item

\begin{tabular}{|c|c|c|c|c|}
\hline Variabel & $\begin{array}{l}\text { Action } \\
\text { Item }\end{array}$ & $\begin{array}{c}\text { Mean } \\
\text { (Importance) }\end{array}$ & $\begin{array}{c}\text { Mean } \\
\text { (Satisfaction) }\end{array}$ & Gap \\
\hline \multicolumn{5}{|c|}{ Kuadran I } \\
\hline Perceived Value & 2 & 4,52 & 3,10 & $-1,42$ \\
\hline Customer Satisfaction & 10 & 4,48 & 3,10 & $-1,38$ \\
\hline \multicolumn{5}{|c|}{ Kuadran II } \\
\hline \multirow{2}{*}{ Perceived Quality } & 1 & 4,48 & 3,52 & $-0,96$ \\
\hline & 3 & 4,52 & 3,52 & $-1,00$ \\
\hline Image & 7 & 4,43 & 3,90 & $-0,53$ \\
\hline Perceived Value & 9 & 4,24 & 3,62 & $-0,59$ \\
\hline Customer Satisfaction & 11 & 4,67 & 3,52 & $-1,15$ \\
\hline \multicolumn{5}{|c|}{ Kuadran III } \\
\hline Perceived Quality & 4 & 3,29 & 3,38 & 0,09 \\
\hline Image & 6 & 2,76 & 3,10 & 0,34 \\
\hline \multicolumn{5}{|c|}{ Kuadran IV } \\
\hline Perceived Quality & 5 & 4,05 & 3,71 & $-0,34$ \\
\hline Perceived Value & 8 & 3,95 & 4,14 & 0,19 \\
\hline
\end{tabular}




\subsection{Analisis Kuadran Keempat Faktor Customer Loyalty}

Analisis terhadap pemetaan keempat faktor loyalitas pelanggan dilakukan untuk melihat tingkat kepentingan dari setiap faktor dan tingkat kepuasan dari action item yang telah dilakukan, sehingga dapat mengetahui faktor mana yang sebaiknya menjadi fokus GMF AeroTrade untuk meningkatkan loyalitas pelanggan (customer loyalty).

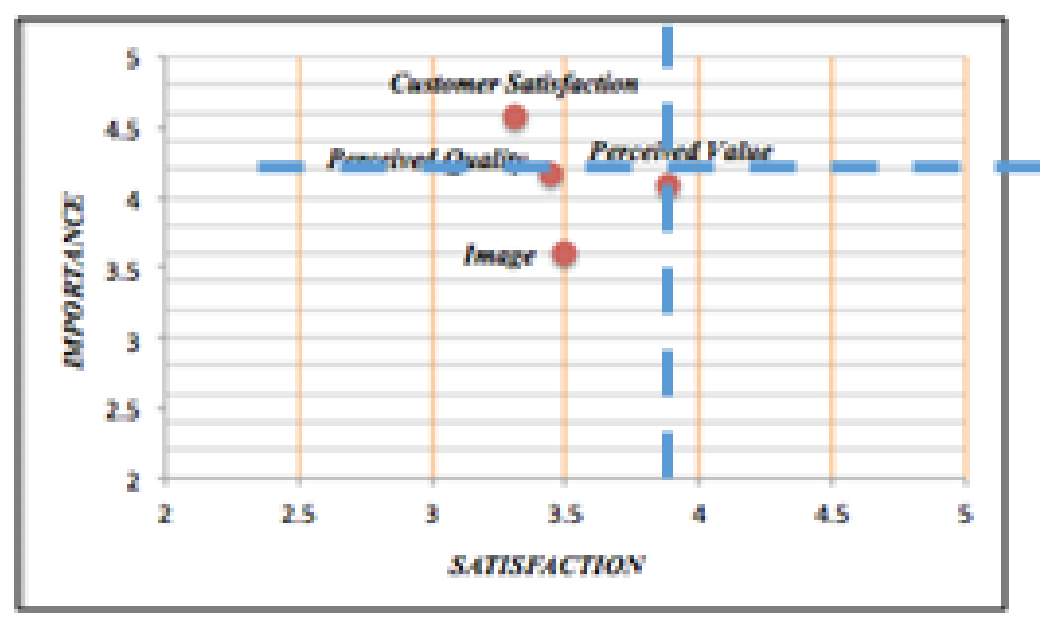

Gambar 5. Kuadran IPA Antar Faktor Customer Loyalty

\section{SIMPULAN}

Tujuan dari penelitian ini adalah untuk mendapatkan hasil dari pengaruh faktorfaktor Image, Perceived Quality, Perceived Value, dan Customer Satisfaction terhadap loyalitas customer (Customer Loyalty) GMF AeroTrade di PT. GMF AeroAsia, serta merumuskan dan menyusun action item yang tepat sehingga dapat memberikan strategi bagi perusahaan untuk mempertahankan dan meningkatkan loyalitas pelanggan. 


\section{REFERENSI}

Analysis, I. (2010). Importance-Satisfaction Analysis \& Matrix Analysis Importance Satisfaction Analysis, (Nov).

Anderson, J. C., \& Gerbing, D. W. (1988). Structural Equation Modeling in Practice: A Review and Recommended Two-Step Approach. Psychological Bulletin, 103, pp. 411-423.

Baker, D. M. A. (2013). Service Quality and Customer Satisfaction in the Airline Industry: A Comparison between Legacy Airlines and Low-Cost Airlines. American Journal of Tourism Research, 2(1), 67-77. http://doi.org/10.11634/216837861302317

Brown, R. (2016). ICF MRO Market Update \& Industry Trends. AP\&M Europe, (May), 0-26.

Chin, W. W., \& Newsted, P. R. (1999). Structural Equation Modeling Analysis with Small Samples Using Partial Least Squares. Statistical Strategies for Small Sample Research, 307-341.

Garson, G. D. (2016). Partial Least Squares: Regression \& Structural Equation Models. G. David Garson and Statistical Associates Publishing.

GMF AeroAsia. (2016). About Us: GMF AeroAsia.s[episMF AeroAsia. GMF towards the Top 10 MRO.

GMF AeroAsia. Investor Relations (2015). Annual Report 2015 World Class MRO of Customer Choice.

Griffin, Abbie ; Hauser, J. R. (1993). The Voice of the Customer. Marketing Science, 12(1), 127. https://doi.org/10.1287/mksc.12.1.1

Gures, N., Arslan, S., \& Yucel Tun, S. (2014). Customer Expectation, Satisfaction and Loyalty Relationship in Turkish Airline Industry. International Journal of Marketing Studies, 6(1), 66-74. http://doi.org/10.5539/ijms.v6n1p66

Hair, J. F., Black, W. C., BJ, B., \& Anderson. (2010). Multivariate Data Analysis. New Jersey: Pearson Prentice Hall.

Hair, J. F., Hult, G. T., Ringle, C. M., \& Sarstedt, M. (2014). A Primer on Partial Least Squares Structural Equation Modeling. Thousand Oaks: Sage. 